\title{
Mineralogical Record for Stepwise Hydroclimatic Changes in Lake Qinghai Sediments Since the Last Glacial Period
}

\author{
Yougui Song ${ }^{1,2, * \mathbb{C}}$, Xiulan Zong ${ }^{1,3}$, Linbo Qian ${ }^{4}$, Huifang Liu ${ }^{1}$, Jibao Dong ${ }^{1,2}$, Hong Chang ${ }^{1,2}$ \\ and Mingyu Zhang ${ }^{5}$ \\ 1 State Key Laboratory of Loess and Quaternary Geology, Institute of Earth Environment, \\ Chinese Academy of Sciences, Xi'an 710061, China; zongxiulan@ieecas.cn (X.Z.); \\ liuhuifang@ieecas.cn (H.L.); djb@ieecas.cn (J.D.); changh@loess.llqg.ac.cn (H.C.) \\ 2 CAS Center for Excellence in Quaternary Science and Global Change, Xi'an 710061, China \\ 3 University of Chinese Academy of Sciences, Beijing 100049, China \\ 4 School of Resource and Environment, Xingtai University, Xingtai 054000, China; linbo0904@163.com \\ 5 Xi'an Institute for Innovative Earth Environment Research, Xi'an 710061, China; zhangmy_66@163.com \\ * Correspondence: syg@ieecas.cn; Tel.: +86-29-6233-6216
}

Received: 10 September 2020; Accepted: 22 October 2020; Published: 28 October 2020

\begin{abstract}
Lake Qinghai is sensitive to climatic changes because of its pivotal location between mid-latitude Westerlies and the low-latitude East Asian monsoon. An $18.6 \mathrm{~m}$ long drilling core (1Fs) from Lake Qinghai provides new information on the hydroclimatic dynamics since the last glacial period. Here, we present the results of bulk mineral assemblages of this core. X-ray diffraction (XRD) results showed that the bulk minerals of the core sediments consist of major clastic minerals (e.g., quartz, feldspar, muscovite), carbonates (e.g., calcite, aragonite, dolomite), and minor clay minerals (e.g., chlorite). Quartz as an exogenous detrital mineral in lake sediments, its abundance is related to lake level changes resulting from regional climate changes via fluvial/aeolian transportation. Aragonite was precipitated from water solutions or chemical alteration of pre-existing minerals or biogenic mediation, closely related to lake hydroclimate change. Mineral assemblages revealed remarkable stepwise hydroclimatic changes. High quartz content and low calcite without aragonite suggested a cold-wet climate condition under predominant westerlies during the last glacial period from 35 to $25.3 \mathrm{ka}$. Afterward, quartz decreased and aragonite occasionally appeared, indicating an unstable hydroclimatic condition during the last deglaciation. Since the Early Holocene (11.9-8.2 ka), predominant minerals shifted from terrigenous quartz to authigenic carbonates, suggesting an increasing lake level, possibly due to intensified Asian summer monsoon with increased effective moisture. Aragonite became the primary carbonate mineral, implying a warming and humid hydroclimate environment with a relatively higher lake-level. During the Middle Holocene (8.2-4.2 ka), aragonite showed a decreasing trend indicating a higher lake level with weak evaporation. During the Late Holocene since $4.2 \mathrm{ka}$, there were lower quartz and aragonite, suggesting a deep lake with a weak summer monsoon. Our quartz and carbonate minerals record provided essential clues to reconstruct hydroclimate change in Lake Qinghai since the last glacial period.
\end{abstract}

Keywords: bulk mineral; quartz; aragonite; carbonate; the last glacial period; Holocene; hydroclimate; Lake Qinghai

\section{Introduction}

Lake Qinghai, located on the Northeast Tibetan Plateau, is situated in the sensitive semi-arid zone between the Asian Summer Monsoon (ASM) -controlled and the Westerlies-influenced areas 
of Asia. Due to its unique geological/geographic settings, Lake Qinghai has become an excellent, world-class site for geoscientific research [1-6]. Over the past thirty years, environmental and climatic reconstructions have been conducted in Lake Qinghai based on various lake sediment cores [1,7-12] and outcrops sections nearby [13-18], and mainly focused on the Holocene climate changes. However, because of the uncertainties of the chronologies and the multiplicity of the proxies used, the impacts of orbital and millennial-scale climate fluctuations in this region are not fully understood. There are different viewpoints regarding hydroclimate in Lake Qinghai since the last glaciation. The interplay of the Westerlies and the ASM inferred from various physical, geochemical, and stable isotopic proxies are often inconsistent. For example, total organic carbon (TOC), grain size, element geochemistry studies suggested Lake Qinghai was characterized by the wettest climate and high lake level during the Early Holocene under the strongest ASM $[1,19,20]$, but optically stimulated luminescence (OSL)-based geomorphic investigations and TOC $\delta^{13} \mathrm{C}$ values, ostracod $\mathrm{Sr} / \mathrm{Ca}$ ratios and Ruppia seeds indicated that it experienced a relatively dry and low lake level under a weak ASM in the Early Holocene [21-23]. Mineralogical composition and particularly carbonate phases are valuable paleoenvironmental proxies. Content of minerals e.g., quartz [24], dolomite [25], and the ratio of minerals such as amphibole/epidote ratio [18] have been used to reflect the intensity of near-surface wind (i.e., below $10 \mathrm{~m}$ ) in Central Asia. However, owing to various sources and complexity of minerals in lake sediments, how to decipher and interpret mineral-bearing environmental information has been a contentious issue for a long time. By now, there are only a few mineral reports on the Lake Qinghai sediments $[5,22,26,27]$. Although previous studies $[5,26,28]$ indicated that the various minerals showed the potential as indicators of climatic variations, the formation mechanism of magnetic mineral, clay mineral, and carbonate minerals of Lake Qinghai and their paleoenvironmental implication is still not well understood. The periodical change of mineral composition can reflect the climatic cycles and lake level fluctuations $[22,29,30]$. The authigenic carbonate minerals in lake sediments can provide useful hydroclimate information in a closed-basin lake [23,31].

Series of long sediment cores recovered by the Lake Qinghai Drilling project funded by the International Continental Scientific Drilling Program (ICDP) and the Chinese government provides a unique opportunity to gain new insight into climate and environmental changes in Lake Qinghai. An $18.6 \mathrm{~m}$ long core at site 1 is dated back to the last glacial period. Multiple physicochemical and paleontological proxies e.g., magnetism, grain size, TOC, Ostracod $\delta^{18} \mathrm{O}$ values, geochemistry, and biomarkers of this core have been reported in previous studies $[1,19,20,27,30,32]$. Based on bulk mineralogical results of the sediments and with comparison to other multi-proxies, this study aims to investigate hydroclimatic changes since the last glacial period.

\section{General Settings}

Lake Qinghai $\left(36^{\circ} 32^{\prime}-37^{\circ} 15^{\prime} \mathrm{N}, 99^{\circ} 36^{\prime}-100^{\circ} 47^{\prime}\right.$ E, elevation $\left.3194 \mathrm{~m}\right)$, a hydrologically closed drainage system, is situated on the northeastern Tibetan Plateau (Figure 1). It is the largest inland brackish lake (the average salinity is $15.5 \mathrm{~g} / \mathrm{L}, \mathrm{pH}=9$ ) in China with a catchment area of $29,660 \mathrm{~km}^{2}$. The average water depth of the lake is $21.0 \mathrm{~m}$, with a water volume of $7.16 \times 10^{10} \mathrm{~m}^{3}$. Water level and lake area have decreased markedly since the 1900s, but increased since 2004, and reached $4476 \mathrm{~km}^{2}$ in 2017 [33]. The lake is mainly recharged by six large rivers and many small creeks, with the Buha River contributing $\sim 50 \%$ of total annual runoff [8], about three times over the northeastern Shaliu River [19]. Glacial meltwater from the surrounding mountains only accounts for $0.3 \%$ of the total inflow to the lake [34]. The water of Lake Qinghai is mainly composed of sodium, magnesium, potassium, chlorine, carbonate, and sulfate ions, and which is originated from the Buha River $(>50 \%)$, the atmospheric deposition (7.4-44\%), and groundwater input (3.7-4.7\%) [34]. The $\mathrm{Ca}^{2+}$ in the lake water is very limited and the carbonate is saturated, and lake sediment consisted of silty clay and authigenic carbonates (aragonite and calcite) $[19,31,35]$. 


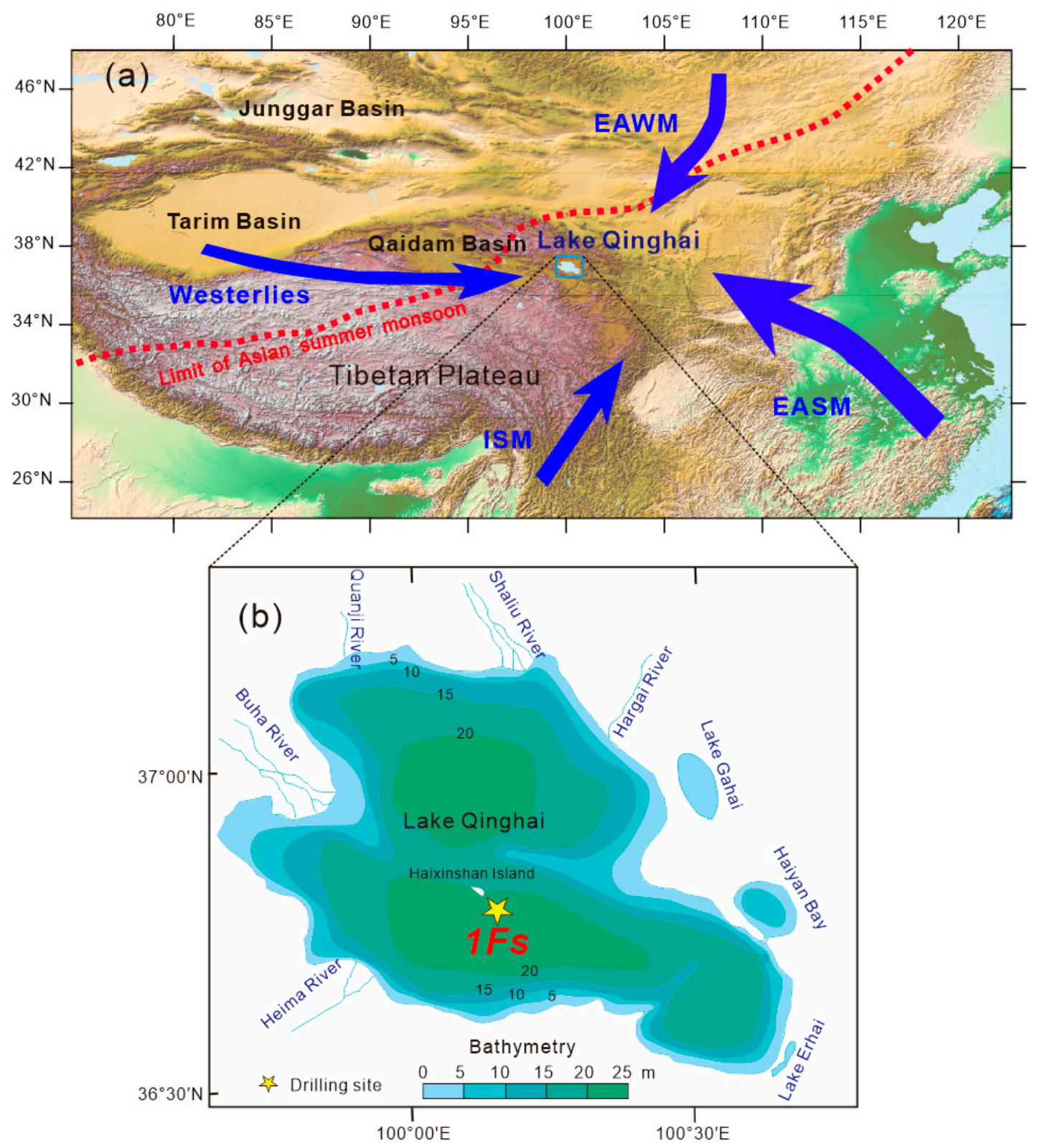

Figure 1. (a) Locations of Lake Qinghai and the western potential dust sources (Tibetan Plateau, Qaidam Basin, Tarim Basin, and Junggar Basin). (b) The bathymetric map of Lake Qinghai and its major feeding rivers (modified from [4]). ISM: Indian summer monsoon EASM: East Asian Summer Monsoon EAWM: East Asian Winter Monsoon.

Lake Qinghai basin consists of predominantly late Paleozoic marine limestone and sandstones, Triassic granite, Mesozoic diorite, and granodiorite with minor late Cambrian phyllite and gneiss. Loess and frozen soil are widely distributed around the lake and strongly influence the lake hydrochemistry within the catchment and material loads. Lake Qinghai is tectonically subdivided into two nearly equal subbasins by an NNW-trending piggy-back horst [36]. Lake Qinghai sediments mainly consist of detrital materials of riverine and/or aeolian origins and authigenic precipitations [4].

The climate in Lake Qinghai is characterized by a typical semi-arid inland temperate continental climate with strong seasonality, mainly influenced by East Asian Monsoon (EAM), Indian summer monsoon (ISM), and middle-latitude westerly atmospheric circulation (Figure 1a). At present, the East Asian Summer Monsoon (EASM) circulation reaches this region in summer, while the Westerlies dominate in winter, resulting in a clear seasonality of precipitation. The mean annual temperature in 
Lake Qinghai Basin varies between 0.9 and $2.7^{\circ} \mathrm{C}$, and the mean annual precipitation is $\sim 380 \mathrm{~mm}$, with more than $65 \%$ occurring in summer, while the potential annual evaporation is up to $1000 \mathrm{~mm}$ at the lake surface [10].

\section{Materials and Methods}

Six cores (named from $1 \mathrm{~A}$ to $1 \mathrm{G})$ at site $1\left(36^{\circ} 48^{\prime} 40.7^{\prime \prime} \mathrm{N}, 100^{\circ} 08^{\prime} 13.5^{\prime \prime} \mathrm{E}, 3194 \mathrm{~m}\right)$ were extracted from the depocenter of the southwestern sub-basin of Lake Qinghai using the GLAD 800 drilling system [36]. Site 1 is located $4.7 \mathrm{~km}$ south to Haixingshan Island and with a $24.71 \mathrm{~m}$ water depth. The composited $18.6 \mathrm{~m}$ long core of lacustrine sediment (1Fs) (Figure 2) was mainly from the core $1 \mathrm{~F}$ and a small part from the core $1 \mathrm{~A}$ based on the correlations of lithological and proxy data [1]. Accelerator mass spectrometry (AMS)- ${ }^{14} \mathrm{C}$ dating of 65 samples including 52 total organic carbon (TOC), 6 Ruppia maritima seeds (from 4.16 to $4.97 \mathrm{~m}$ ), and 7 plant remains samples (from 6.70 to $8.38 \mathrm{~m}$ ) were measured at the AMS Laboratory in Institute of Earth Environment, Chinese Academy of Sciences (IEECAS), Xi'an, Republic of China, and NSF-Arizona AMS Laboratory, University of Arizona, Tucson, AZ, USA [1,37]. However, there are eight anomalous age points because of the incorporation of this old carbon from meltwater during early deglaciation. The remaining 57 dates were used to establish the age model for 1Fs after calibration using CALIB 510 and CALPAL2007 by piecewise linear regression. This age model suggested that the sediment core spans nearly 32 ka (cal. kyr BP) [1,37]. For details, please see references [1,37] how to carry out ${ }^{14} \mathrm{C}$ dating, data analysis, and old carbon correction.

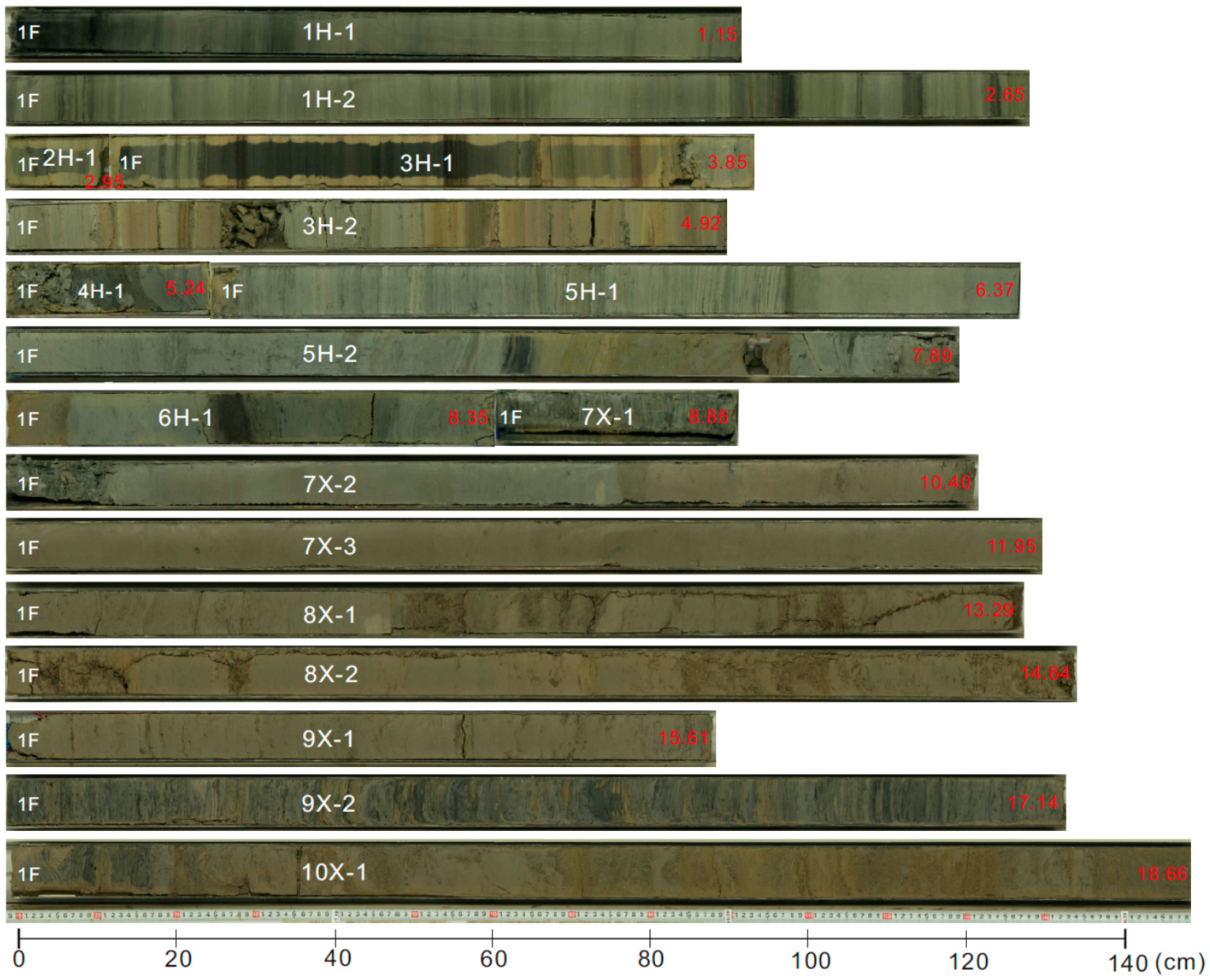

Figure 2. Photos of 1Fs core from the center of Lake Qinghai. 
However, this piecewise linear regression age model does not consider the error range of the dated ${ }^{14} \mathrm{C}$ age, a Bayesian age-depth model can provide more realistic precision estimates for the geochronology of sediments [38]. A bayesian age model based on the 52 AMS ${ }^{14} \mathrm{C}$ dates (Table 1) was established for the 1Fs core (Figure 3) with the BACON 2.2 program $[39,40]$. All radiocarbon dates were calibrated to calendar years (i.e., cal kyr BP, hereafter ka) using the IntCal13 (Northern Hemisphere terrestrial calibration) [40] in the Bacon code, $\mathrm{cc}=1$. We set the parameters to their default values: accumulation (acc.) shape $=1.5$ for the gamma distribution; memory (mem.) mean $=0.7$ and mem.strength $=4$ for the beta distribution. The mean accumulation rate was changed to $20 \mathrm{y} \mathrm{cm}^{-1}$ according to information available from calibrated ${ }^{14} \mathrm{C}$ dates $(1773 \mathrm{~cm}$ thickness; $\sim 33.6 \mathrm{ka}$ ) (Figure 3). The result of Bayesian age-model indicate the bottom age at $18.6 \mathrm{~m}$ in depth can extend to $34.5 \mathrm{ka}$ (Figures 3 and 4), which is $2.5 \mathrm{kyr}$ older than previous piecewise linear regressions age [1,37].
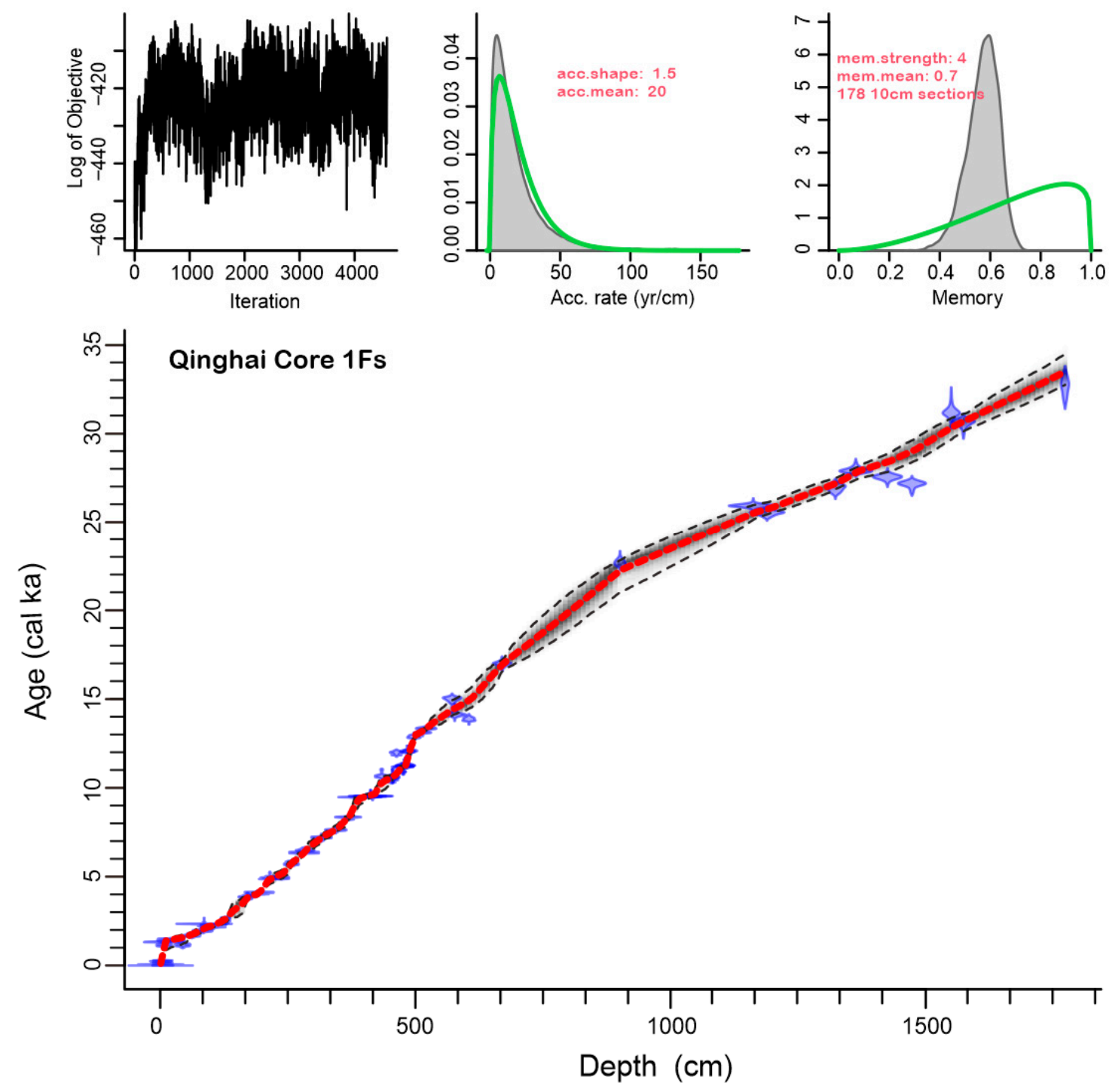

Figure 3. Bayesian age-depth model of the 1 Fs core (weighted mean age, dotted red line), overlaying the calibrated distributions of individual ${ }^{14} \mathrm{C}$ ages (blue), with $95 \%$ probability intervals (gray shaded area). The three small panels show the prior information: time series of the log-posterior for the subsampled Markov Chain Monte Carlo (MCMC), prior (green), and posterior (gray) for accumulation rate (yr/cm). 
Table 1. Age Data from 1Fs Core of Lake Qinghai [1] Used to Establish Age-Depth Model.

\begin{tabular}{|c|c|c|c|c|c|c|c|}
\hline \multirow[t]{2}{*}{ Lab Code } & \multirow[t]{2}{*}{ Depth (cm) } & \multirow[t]{2}{*}{ Date Material } & \multicolumn{2}{|c|}{$\begin{array}{c}\text { Measured }{ }^{14} \mathrm{C} \text { Age } \\
\text { (yr BP) }\end{array}$} & \multicolumn{3}{|c|}{$\begin{array}{l}\text { Calibrated Age } \\
\text { (Cal yr BP) }\end{array}$} \\
\hline & & & 14C Age & Error & Lower & Upper & Median \\
\hline AA78739 & 1 & TOC & 30 & 30 & 30 & 140 & 60 \\
\hline AA78740 & 5 & TOC & 200 & 35 & 80 & 310 & 180 \\
\hline XA2718 & 8 & TOC & 1210 & 40 & 1060 & 1260 & 1140 \\
\hline XA1748 & 9 & TOC & 1430 & 30 & 1290 & 1380 & 1330 \\
\hline XA2730 & 21 & TOC & 1550 & 20 & 1390 & 1520 & 1470 \\
\hline XA2771 & 44 & TOC & 1220 & 40 & 1060 & 1270 & 1150 \\
\hline XA2770 & 62 & TOC & 1780 & 40 & 1570 & 1820 & 1700 \\
\hline XA2769 & 83 & TOC & 2000 & 40 & 1870 & 2060 & 1950 \\
\hline XA2721 & 86 & TOC & 2310 & 30 & 2190 & 2360 & 2340 \\
\hline XA2711 & 104 & TOC & 2180 & 20 & 2130 & 2310 & 2240 \\
\hline XA2768 & 128 & TOC & 2470 & 40 & 2360 & 2710 & 2560 \\
\hline XA2766 & 171 & TOC & 3565 & 40 & 3720 & 3970 & 3865 \\
\hline XA2713 & 194 & TOC & 3740 & 20 & 3990 & 4220 & 4110 \\
\hline XA2765 & 215 & TOC & 4340 & 40 & 4840 & 5040 & 4920 \\
\hline XA2764 & 238 & TOC & 4380 & 40 & 4860 & 5050 & 4940 \\
\hline XA2763 & 257 & TOC & 4990 & 50 & 5610 & 5890 & 5720 \\
\hline XA2700 & 282 & TOC & 5570 & 20 & 6310 & 6400 & 6350 \\
\hline AA77753 * & 284 & TOC & 5708 & 40 & 6380 & 6620 & 6498 \\
\hline XA2762 & 316 & TOC & 6270 & 40 & 7030 & 7270 & 7210 \\
\hline XA2759 & 344 & TOC & 6780 & 55 & 7520 & 7720 & 7630 \\
\hline XA2758 & 368 & TOC & 7510 & 40 & 8200 & 8400 & 8335 \\
\hline XA2716 & 391 & TOC & 8450 & 30 & 9440 & 9530 & 9485 \\
\hline XA2757 & 412 & TOC & 8600 & 50 & 9500 & 9680 & 9560 \\
\hline XA1756* & 413 & TOC & 8580 & 45 & 9485 & 9665 & 9540 \\
\hline AA77711 & 416 & seed & 8540 & 50 & 9470 & 9580 & 9520 \\
\hline XA2756 & 434 & TOC & 9430 & 50 & 10,520 & 11,060 & 10,660 \\
\hline AA77712 & 454 & seed & 9280 & 50 & 10,280 & 10,580 & 10,460 \\
\hline XA2755 & 455 & TOC & 9370 & 50 & 10,430 & 10,720 & 10,590 \\
\hline AA77760 & 456 & TOC & 9410 & 60 & 10,430 & 11,060 & 10,640 \\
\hline XA3200 & 463 & TOC & 10,235 & 30 & 11,830 & 12,080 & 11,990 \\
\hline XA1586* & 475 & seed & 9720 & 47 & 10,917 & 11,230 & 11,148 \\
\hline AA78019 & 477 & TOC & 9755 & 60 & 10,880 & 11,270 & 11,190 \\
\hline XA2701 & 480 & TOC & 9900 & 45 & 11,210 & 11,590 & 11,290 \\
\hline AA77761 & 481 & TOC & 9890 & 50 & 11,200 & 11,600 & 11,290 \\
\hline XA3195 & 485 & TOC & 10,290 & 30 & 11,840 & 12,230 & 12,070 \\
\hline XA3194 & 490 & TOC & 10,310 & 30 & 11,990 & 12,350 & 12,100 \\
\hline XA1752 & 497 & seed & 11,020 & 35 & 12,880 & 13,050 & 12,940 \\
\hline XA2754 & 514 & TOC & 11,280 & 60 & 13,080 & 13,270 & 13,170 \\
\hline XA3210 & 521 & TOC & 11,510 & 30 & 13,270 & 13,430 & 13,350 \\
\hline XA3226 & 572 & TOC & 12,630 & 40 & 14,670 & 15,130 & 14,910 \\
\hline XA2752 & 577 & TOC & 12,230 & 50 & 13,920 & 14,250 & 14,090 \\
\hline AA77765 & 605 & TOC & 12,010 & 60 & 13,750 & 14,000 & 13,870 \\
\hline AA78823 & 901 & TOC & 18,820 & 130 & 22,130 & 22,590 & 22,360 \\
\hline XA3229 & 1162 & TOC & 21,680 & 70 & 25,370 & 26,420 & 25,880 \\
\hline XА3963 & 1189 & TOC & 21,190 & 70 & 25,390 & 26,000 & 25,570 \\
\hline XA2777 & 1323 & TOC & 22,620 & 100 & 26,960 & 27,730 & 27,370 \\
\hline XA2705 & 1363 & TOC & 23,900 & 90 & 28,380 & 29,150 & 28,730 \\
\hline XA2776 & 1425 & TOC & 23,350 & 160 & 27,910 & 28,330 & 28,130 \\
\hline XA2775 & 1473 & TOC & 22,810 & 100 & 27,070 & 27,880 & 27,540 \\
\hline AA77785 & 1550 & TOC & 27,250 & 335 & 31,690 & 32,200 & 31,940 \\
\hline XA2774 & 1574 & TOC & 26,330 & 150 & 30,810 & 31,510 & 31,210 \\
\hline AA77790 & 1773 & TOC & 28,670 & 300 & 32,665 & 33,605 & 33,150 \\
\hline
\end{tabular}

* Average values of 2-3 samples. 


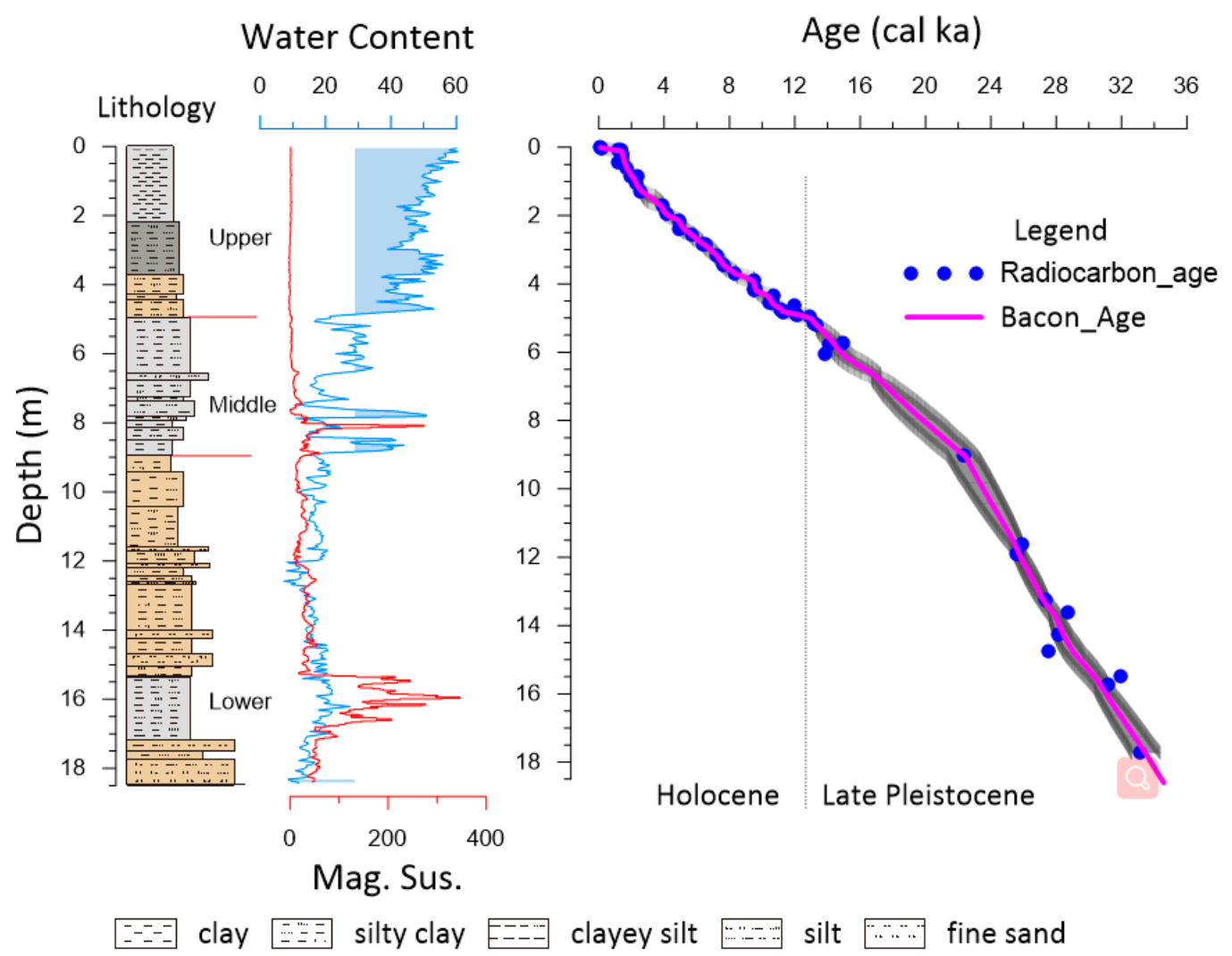

Figure 4. Lithology, water content, magnetic susceptibility, and carbon dates for 1Fs core (The accelerator mass spectrometry (AMS) ${ }^{14} \mathrm{C}$ data are from An et al., (2012) [1] and Zhou et al., (2014) [37]).

Magnetic susceptibility was measured at $2.5-\mathrm{cm}$ intervals on the whole core using a GEOTEK Multi-Sensor Core Logger (MSCL) in the onshore lab. The susceptibility reading was recorded as volume-normalized susceptibility in units of $10^{-6}$ SI. Water content is defined as the percent proportion of the loss mass at $105{ }^{\circ} \mathrm{C}$ oven to total wet sediment. A total of 367 bulk samples were collected at a $5 \mathrm{~cm}$ interval for the identification of bulk mineral compositions. The air-dried sediments were ground by hand with an agate mortar and pestle to about 300 mesh size $(<40 \mu \mathrm{m})$, then the powder was scanned from $5^{\circ}$ to $45^{\circ}(2 \theta)$ with a Philips X'pert Pro (PW3071) X-ray diffractometer using $40 \mathrm{~mA}, 40 \mathrm{kV}$ generator settings, and $1.540598 \AA \mathrm{CuKa}$ radiation. Minerals were identified with reference to patterns in the Powder Diffraction File (PDF 2004) using Panalytical Highscore software (ver. 1.0e) (Almelo, The Netherlands) and based on mineral Relative Intensity Ratios (RIR), and the Levenberg-Marquardt (LM) method of qualitative analysis was also applied to compute the contents [41,42]. The bulk chemistry of samples was determined by X-ray fluorescence analyses (Axios advanced, PW4400). The above experiment was conducted in the State Key Laboratory of Loess and Quaternary Geology, IEECAS. The other physical-chemical proxies are from the published literature $[1,8,20]$.

\section{Results}

\subsection{Lithostratigraphic Units}

Core $1 \mathrm{~F}$ was divided into three lithostratigraphic units (Figure 4) based on the correlations of multi-proxies e.g., color, grain size, the abundance in calcium carbonate and organic carbon [1]. The upper $5.0 \mathrm{~m}$ is mainly composed of dark gray to light brown lacustrine silt clay or clay with obviously laminated sediments (Figure 2). It has the highest water content (average $48.5 \%$ ) with an upward increasing upward trend and lowest magnetic susceptibility $\left(<3 \times 10^{-6} \mathrm{SI}\right)$ (Figure 4$)$. 
The middle unit (5.0-9.0 m) consists of gray and grayish-yellow silty clay with silt layers (Figure 2). Amplitudes of variation of water content and magnetic susceptibility are greater, indicating an unstable hydroclimate environment. There are three peaks in the curve of water content, but only one peak of magnetic susceptibility at $8 \mathrm{~m}$ in depth (Figure 4). Light brown and gray silty clay, with loess-like silt and fine sand layers, are present in the lower part (9.0-18.6 m) of the core (Figure 2). This lithostratigraphic subdivision generally is consistent with the change of water contents. Water contents show a general increasing trend from the bottom to the top (Figure 4), the average water content increase from $19.2 \%$ in the lower parts to $48.6 \%$ in the upper part. However, it differs from magnetic susceptibility, which has an upward stepwise declining trend with a peak at the depths from $15.5 \mathrm{~m}$ to $18 \mathrm{~m}$ (Figure 4).

\subsection{Bulk Mineral Composition}

XRD analysis with Highscore software showed that the bulk minerals in 1Fs sediments consist of clastic minerals (e.g., quartz, feldspar, muscovite), carbonates (e.g., calcite, aragonite, dolomite), and minor clay minerals (e.g., chlorite) (Figure 5). Quartz and carbonates are predominant minerals in the sediments, their contents variations are employed to understand wind/hydrodynamic, lake salinity, and lake temperature, which is ultimately related to climatic and palaeoenvironmental changes. The predominant mineralogical components of the $1 \mathrm{Fs}$ lacustrine sediments change from quartz to aragonite from the lower to the upper. Carbonate minerals of bottom sediments are mostly composed of calcite and dolomite without aragonite, but aragonite predominates in the upper $5 \mathrm{~m}$ sediments. According to the above stepwise variation characteristics, we divide the curves into three stages (I-II) at the depths of $11.5 \mathrm{~m}$ and $5 \mathrm{~m}$ (Figure 6), although no significant lithological transition around $11.5 \mathrm{~m}$ in depth was observed. This boundary is also not clear in magnetic susceptibility (Figure 4) but is evident in the grain size record $[1,20]$.

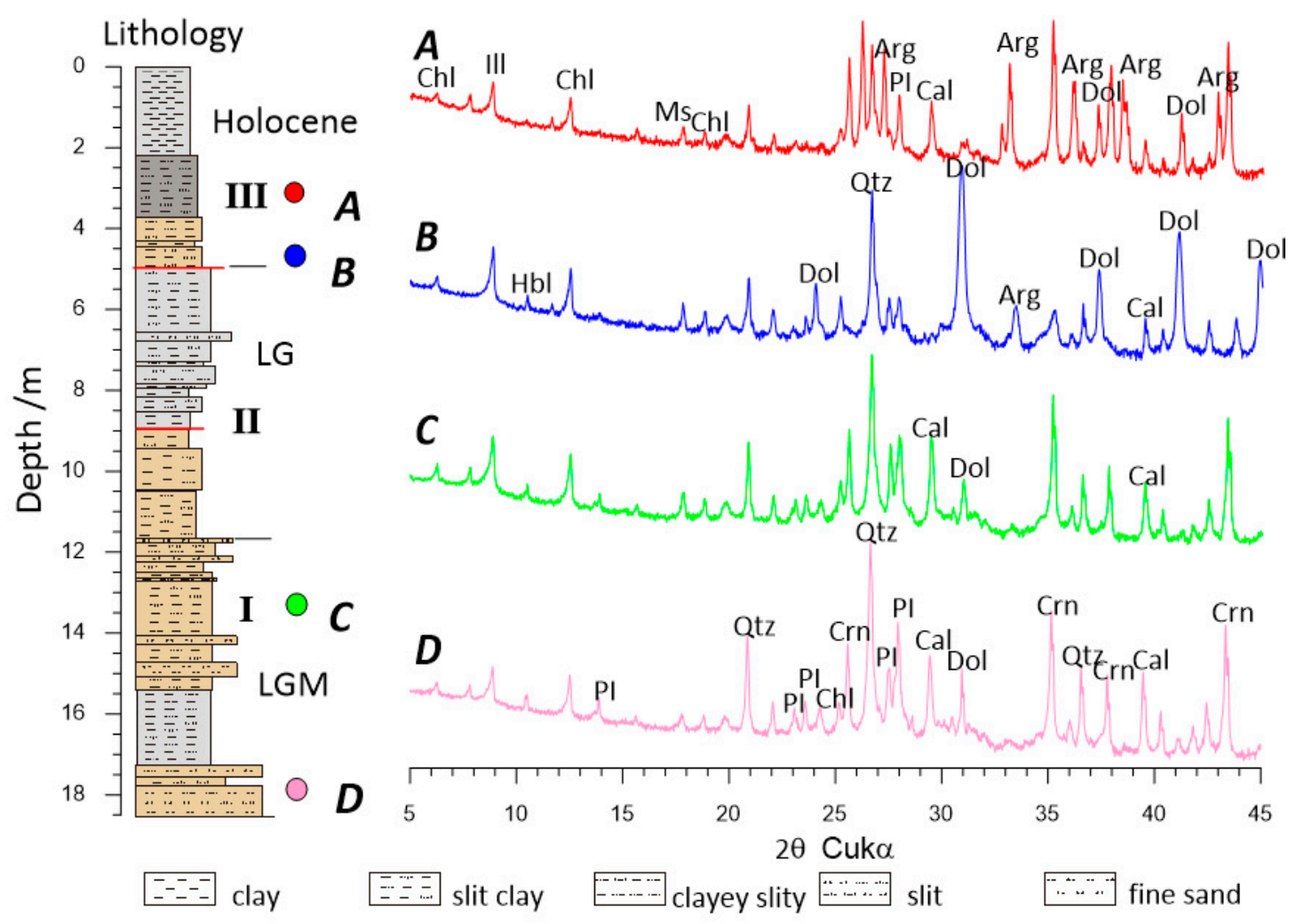

Figure 5. Representative XRD patterns of 1Fs core. Arg: Aragonite; Cal: Calcite; Dol: Dolomite; Chl: Chlorite; Ill: Illite; Qtz: Quartz; PI: Plagioclase; Ms: Muscovite; Crn: Corundum; Hbl: Hornblende; LG: Lateglacial; LGM: Last Glacial Maximum. 


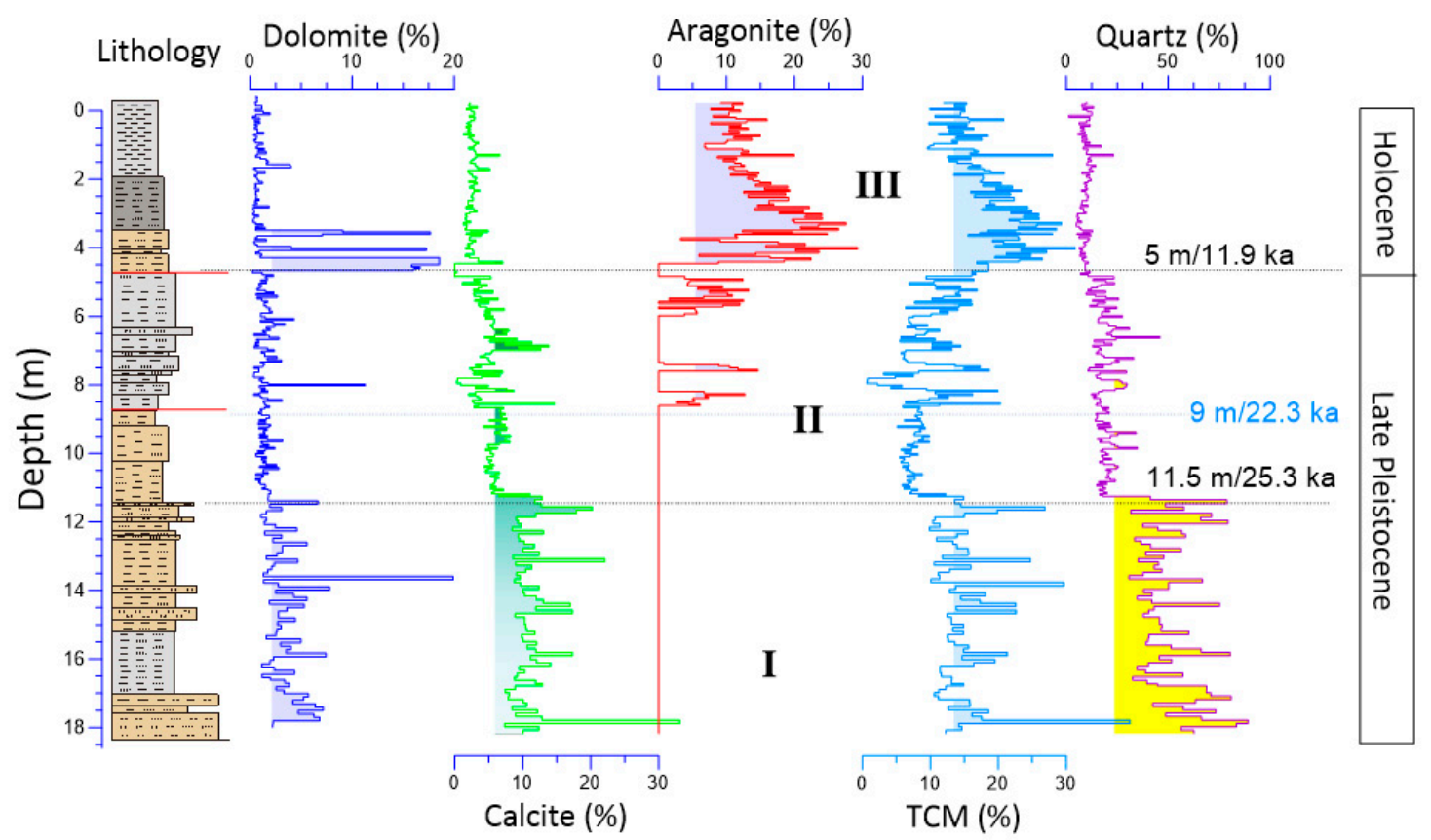

Figure 6. Lithology and downhole variations of carbonate minerals and quartz content in 1Fs core sediments. TCM: Total carbonate minerals including calcite, aragonite, and dolomite. The shadows indicate the values are higher than the average. The lithological legend is the same as Figure 3.

Stage I from $35 \mathrm{ka}$ to $25.3 \mathrm{ka}$ is involved in late Marine Isotope Stage (MIS) 3 and Early MIS2. Stage II is spanning from $25.3 \mathrm{ka}$ to $12.9 \mathrm{ka}$ (11.5-5 $\mathrm{m}$ in depth), including Last Glacial Maximum (LGM) and Lateglacial. Stage III from $11.6 \mathrm{ka}$ to present (the upper $5 \mathrm{~m}$ ) is the Holocene. Quartz content shows a general stepwise decreasing trend from an average at $50 \%$ in stage III to $10 \%$ in stage I, but the total contents of carbonate minerals reach the lowest value in stage II. The composition of carbonate has experienced significant change, that is, calcite is the dominant minerals during stage III, but the predominant carbonate mineral is calcite during stage I. The dolomite in this core is minor with relatively low concentration. It is worthy to note that (1) The variation trend of calcite content is like that of quartz (Figure 6), which could mean similar detrital source; (2) Predominant minerals shift from detrital quartz to authigenic carbonate mineral (main aragonite) from stage I to stage III. (3) These three stepwise changes are different to the previous lithologic strata and indicators.

\section{Discussion}

\subsection{Hydroclimatic Significance of Minerals}

Previous studies $[9,19,30,31,43]$ documented that the mineral composition of lake sediments is closely related to the catchment rock, hydrology, and climate changes and that our results also prove this. We found that the variations of contents and types of minerals in this core could be used to reconstruct the hydroclimate changes history. In terms of origin, minerals in the lake sediments can be classified into 2 types: exogenous mineral and endogenous (authigenic) minerals [9,30,31]. Exogenous minerals are detrital matter transported by surface runoff, wind and glacier transport, shore erosion, composition, and content related to catchment rocks, weathering and transporting processes, and climate condition. The authigenic minerals mainly reflect the chemical precipitation and biological states and their changes in the lake system [7,30,31]. Atmospheric dust and lake's authigenic carbonate play a significant role in modern lacustrine sediments in Lake Qinghai [44,45], among which the contribution of the authigenic carbonate was about 22\% [45]. The lake water salinity [19] and the chemistry of brines [46] and pore water [47] in the closed endorheic lake affect the authigenic mineral fabric, precipitation and transition [7,12,31]. Intense evaporation (3-4 times greater than 
precipitation) in the semiarid area could cause lake water salinization because of the enrichment of $\mathrm{Na}^{+}, \mathrm{Mg}^{2+}, \mathrm{Cl}^{-}$, and $\mathrm{HCO}_{3}{ }^{-}$[19]. The supersaturated lake water is helpful to precipitation of authigenic carbonates (aragonite dominance) to the lake floor. Water type (runoff, meltwater, and/or groundwater) plays an important role in the development of the different mineral phases. Therefore, the mineralogical properties of the lake can provide valuable information for the reconstruction of the hydroclimatic environment.

\subsubsection{Quartz}

The physical and chemical properties of quartz are extremely stable in the supergene environment and show low sensitivities to weathering and post sedimentary environments, but it can provide important source information [48,49]. Quartz is the most common exogenous detrital mineral in lake sediments. Quartz in lacustrine sediments has two potential sources, i.e., aeolian and hydromorphic (e.g., fluvial, meltwater transport) [24,50]. The quartz content in the lake deposit center is related to many factors e.g., riverine runoff, lake hydrology condition (here mainly related to lake level, water depth, and volume)and local climate condition [51,52]. Generally, a higher percentage of quartz suggests more exogenous materials transported by strong hydrological dynamics or intensified wind related to climate change. The runoff flowing into the lake determines the total quartz input carried by the river into the lake. The quartz content and grain size in the lake center are related to the distance from the shoreline especially to the mouth of the river [51-53]. Weak hydrological dynamic and long-distance transportation make the input materials especially coarse and heavy fractions difficult to reach the lake center, resulting in a decrease in the available materials supply including quartz. In other words, large water volume is unfavorable to accept more quartz. The concentration of the quartz is low, if the lake is deeper, the deposit of quartz in the center of the lake is less. Grain size distribution curves [1,20], geochemistry [44], lithological and micromorphological features [31,50], and suggested that the main components of sediments are replaced aeolian by fluvial or lacustrine sediments from late Pleistocene to Holocene.

The changes in runoff and lake hydrology finally were determined by climatic conditions. The warm-wet climate is helpful to the growth of watershed vegetation, which can buffer physical erosion, due to which visibly increases clay content, at the same time, the warm-wet climate can promote chemical weathering, and biological processes, which can be one of the main causes of finer fraction sediments (clay). All these factors may cause a decrease in the percentage of quartz content; therefore, quartz content is low under warm-wet conditions. On the one hand, the cold-dry climate with relatively weak chemical weathering and intense physical weathering increase the proportion of quartz in the clastic minerals. At the same time, the lake water level is lower [8,23], and the river mouth is nearer to the center of the lake. Additionally, the wind will transport more dust into the lake [44]. Generally speaking, the climate is cold and dry, and the content of detrital quartz in the rivers is high. Although the amount of quartz brought into the lake by water is relatively small in the wet season, more quartz can enter the center of the lake because the lake is shallow, and the amount of quartz brought into the lake by wind is also high. Therefore, high quartz content corresponds to the shallow lake, cold and dry climatic conditions, while lower quartz content corresponds to deep lake, warm and wet climate.

\subsubsection{Carbonate Minerals}

Origin of carbonates in lacustrine sediments is usually explained by detrital (allogenic) genesis (e.g., clastic input and aeolian supply) as well as by endogenic precipitation including concentration through evaporation and biogenic mediation or authigenic (precipitated from water solutions or chemical alteration of pre-existing minerals) $[43,54]$. The $\mathrm{Ca}^{2+}$ concentrations in modern lake water are much low ( 11 ppm) than those in major input rivers e.g., the Buha River ( $\sim 56-70 \mathrm{ppm})$ around lake Qinghai. In contrast, total dissolved inorganic carbon concentration is relatively high ( 291 ppm) [34]. $\mathrm{Ti}$ is heavy and not soluble, and Ca is more active than Ti. We assumed that the Ti concentration is 
relatively stable (its source rock did not change during such a short period), the carbonate chemistry of the lake is calcium-limited, indicating that carbonate precipitation in the sediments closely relates to $\mathrm{Ca}^{2+}$ delivered by river runoff. Therefore, the $\mathrm{Ca} / \mathrm{Ti}$ ratio in the Qinghai Lake core can be used as an indicator of river runoff [55]. Carbonate content in recent sediments covaries with the observed water discharge of the Buha River, which in turn relates to precipitation. Modern process studies indicate the predominant carbonate minerals in the lacustrine detrital sediments and suspended matter from riverine water is calcite in low concentrations [19,22]. Increased carbonate-rich dust fallout during springtime may facilitate more calcite precipitation. The variation similarity between calcite and quartz suggests that they have the same source, calcite is allochthonous input. However, it cannot exclude the contributions of authigenic calcite and dolomite because of the enhancement of biochemical precipitation and increasing of brine salinity.

Carbonate content is particularly sensitive to climate change because their dissolution, migration, and leaching loss are strongly influenced by precipitation, temperature, and $\mathrm{CO}_{2}$ concentration $[22,43,56]$. Carbonate content in the Lake Qinghai sediments was used as an indicator of river runoff. Furthermore, it is further interpreted as indicators of the strength of the Asian summer monsoon. Warm and wet intervals, associated with increased monsoon strength, are indicated by high carbonate [55]. During interglacial periods, strong Asia summer monsoon increased meteoric precipitation but also higher evaporation rates in summer. Enhanced evaporation rates and possibly high productivity within the stratified surface water eventually leads to carbonate supersaturation and due to the high $\mathrm{Mg} / \mathrm{Ca}$ ratio of the lake water, aragonite precipitation. In contrast, during colder or cooling glacials/stadials, the peak runoff (due to meltwater) would occur later in the year, summer surface water stratification would be decreased or shorter, and productivity likely lower. Aragonite precipitation might have been reduced. Yu and Kelts [23] considered that carbonate minerals from both Holocene sediment cores and modern taps are autochthonously formed in the lake. Our results also showed aragonite is the predominant carbonate mineral in Holocene sediments (Figure 5). Aragonite is widespread in lacustrine sediments and suspended matter of Lake Qinghai, it is often tacitly assumed to be authigenic, precipitates in high $\mathrm{Mg} / \mathrm{Ca}$ lake water [22,57]. The high content of aragonite reflects a warm and humid environment while a low content of aragonite reflects a cold and dry climate in Lake Qinghai [22,30].

\subsection{Stepwise Hydroclimate Dynamics Since the Last Glacial Period}

Nowadays, the hydroclimate at Lake Qinghai is mainly affected by the convergence of the middle-latitude Westerlies and Asian monsoon (Figure 1). Quaternary loess and alluvial/lacustrine sediments cover about one-fifth of the whole Lake Qinghai catchment $[29,46]$. The previous investigation on color, grain size, geochemistry, and morphology of sediments $[1,6,19,20]$ suggested abundant aeolian components (dust input) in core sediments. For example, grain-size distribution patterns of the lower sediments in core 1Fs are similar to typical aeolian loess [20]. However, the upper sediments have more hydromorphic components. Lister et al. [12] described yellow-brown sediments in core 14B entering Lake Qinghai as underwater loess deposition during the Holocene. These available sedimentological records help us to study the relationship between dust input and lacustrine precipitates with the regional hydroclimate dynamics. WI (Westerlies Index) and SMI (Summer Monsoon Index) proxies suggest that the Westerlies gradually weakened since the last glacial period while the ASM climate intensified since at LGM, especially after $11.9 \mathrm{ka}$ (Figure 7). Moreover, the minerals records indicate three stepwise hydroclimate changes (stage I to stage III) over the last $35 \mathrm{ka}$.

During stage, I (35-25.3 ka), silty clay with loess-like silt and fine sand layers dominate the lake sediments (Figure 2), characterized by low water content (Figure 4) and high quartz (Figures 6 and $7 \mathrm{f}$ ) and calcite concentrations (Figure 6), and also the peak of magnetic susceptibility (Figure 4). As mentioned above that the quartz and calcite are exogenous detrital minerals transported by wind or fluvial, but Summer Monsoon Index (SMI) suggests that the ASM is very weak, and its front rarely penetrated sufficiently northwest to reach Lake Qinghai [1]. There is no enough moisture 
to form monsoonal precipitation. While Westerlies climate index (WI, the flux of $>25 \mu \mathrm{m}$ fraction) indicated that the mid-latitude strong Westerlies climate with larger variability dominated the Lake Qinghai area during the last glacial period (Figure $7 \mathrm{~h}$ ), which could transport more dust into the lake. Talbot and Kelts [58] considered that calcite is easy to be formed under the condition of low temperature and little evaporation of lake water. No aragonite (Figures 6 and 7a) and abundant calcite (Figure 6) suggested the lower productivity of lake and weak evaporation under cooler and arid climate from late MIS3 (35 to $26 \mathrm{ka}$ ) to early MIS2 (26-18 ka), which is generally coincident with mean effective moisture in the Asian monsoon margin [59]. Ca/Ti ratio in Lake Qinghai sediments is closely related to river runoff [55], the low $\mathrm{Ca} / \mathrm{Ti}$ platform (Figure $7 \mathrm{~b}$ ) suggests less river runoff. The weak runoff and dry climate also support that the sediments have abundant dust materials provided by Westerlies during the glacial/stadial period. Dominant ostracod species Ilyocypris bradyi (Figure 7i) with low $\delta^{18} \mathrm{O}$ values in this core during the last glacial period showed that Lake Qinghai was small in size or even consisted of several playa lakes [8]. This climate and hydrologic environment are favorable to produce coarser dust (Figure $7 \mathrm{~g}$ ), which provides stable aeolian materials to the lake. The grain size distribution of loess-like sediments in the lower part is similar to that of modern dust and aeolian loess [1], indicating that the sediment during this period came from aeolian dust. All the above results suggest that Lake Qinghai had a shallow water level even desiccated during this period, and its sediments were predominated by aeolian dust deposition under a dry glacial condition with weak summer monsoon and strong westerlies.

During stage II (25.3-11.9 ka), corresponding to the middle unit (11.65-5 m) of core 1Fs, the lithology shifts to grayish-yellow silty clay with silt layers. It is noted that aragonite precipitation has three peaks around $21 \mathrm{ka}, 19 \mathrm{ka}$, and the Bølling-Allerød (B/A) (15.2-13.4 ka), but aragonite content showed near-zero levels around the Younger Dryas (YD, 13.1-12.2 ka) (Figure 7a). Generally, calcium becomes the key-limiting element in Lake Qinghai, where any available $\mathrm{Ca}^{2+}\left(\right.$ and $\left.\mathrm{Sr}^{2+}\right)$ from rivers would be rapidly removed by precipitation of authigenic carbonates [34]. Thus, aragonite precipitation during $21 \mathrm{ka}$ and $19 \mathrm{ka}$ would be attributable to high latitude Melt Water Pulse (MWP) events during MIS 2 stage [11]. The seasonal meltwater also caused lower ostracod $\delta^{18} \mathrm{O}$ values during the LGM and early Lateglacial period [8]. The relatively stable mineral compositions were interrupted by the riverine $\mathrm{Ca}^{2+}$ and $\mathrm{Sr}^{2+}$ input derived from the catchment weathering, which was interpreted to be a crucial hydrological event or the melting of frozen soil surrounding the lake. During the Lateglacial period, the lake did not desiccate completely and was occupied occasionally by shallow water [32]. Dust deposits dominated between $26 \mathrm{ka}$ and $12.6 \mathrm{ka}$ (YD), possibly linked to prevailing westerly winds [1,19,59-62]. These fluctuations reveal the alternations between aeolian and riverine inputs under unstable transitional conditions during the deglaciation. These large-amplitude climate change correlated well with changes in the speleothem $\delta^{18} \mathrm{O}$ records [63-65] and loess deposits in the westerlies-dominated Ili Basin $[25,66]$.

During stage III (<11.9 ka), the lithology of Lake Qinghai sediments changed significantly from aeolian-dominated facies during the LGM to lacustrine-dominated facies in the uppermost $5 \mathrm{~m}$, which is mainly composed of silty clay or clay with horizontal bedding (Figure 2). A dramatic shift from exogenous detrital mineral to authigenic mineral occurs from the Lateglacial to the Holocene (Figure 7), which implies the radical change of lake sediment environment and climate. During the Holocene period, the contents of quartz, calcite keep low, and aragonite precipitate in larger abundance $(10-20 \%)$. The particle size distribution of upper $0.1 \mathrm{~m}$ lacustrine clayey silt of $1 \mathrm{Fs}$ is similar to suspended particles of the Buha River, implying that fine sediments mainly derive from river runoff [1]. The river runoff is the primary source of lake material because of the warm and humid Holocene climate. $\mathrm{Ca}$ and $\mathrm{Sr}$ are readily transported into Lake Qinghai in dissolved forms by rivers and subsequently leached by precipitation of authigenic carbonates [35]. Thus, the appearance and fluctuation of the authigenic aragonite along with clay suggests an alteration to high regional runoff and rainfall. In addition, high-intensity evaporation and high temperature promote a large amount of aragonite precipitation [67]. 
The Holocene can still be further divided into three stages based on minerals components: Early Holocene is characterized by fluctuating increasing aragonite (Figure 8a) and decreasing quartz (Figure $8 \mathrm{~d}$ ), which is consistent with highly effective moisture (Figure $8 \mathrm{~b}$ ) and relatively weak hydrodynamic condition (Figure 8d). Although Ca/Ti (Figure 8c), SMI (Figure 8b,f), and TOC flux (Figure 8g) indicating an increasing runoff, strengthening summer monsoon (Figure $8 \mathrm{~h}$ ) and high precipitation, respectively, but the high temperature and evaporation are favorable to form authigenic aragonite, The enriched $\delta^{13} \mathrm{C}_{\text {org }}$ values of TOC in the $1 \mathrm{~F}$ core (Figure 8e) indicate that the lake level was low (less than $10 \mathrm{~m}$ ) in the Early Holocene. The disappearance of freshwater Ostracod species (e.g., I. bradyi) and the emergence of salty Ostracod species (e.g., L. Inopinata) also supported strong precipitation-evaporation balances in Early Holocene (Figure 7i) [8]. The more negative value of the oxygen isotope of ostracod indicates that the water supply is sufficient, and the climate is warm and humid. In combination with the continuous high content of aragonite (Figure 8b), it could be speculated that a warm and humid climate with high evaporation prevailed in the Early Holocene. The mineral sequence calcite, $\mathrm{Mg}$ calcite-aragonite-dolomite as a surrogate, increases with salinity in lacustrine sequences [58]. The greater evaporation in this region promotes the enrichment of $\mathrm{Mg}^{2+}$, and $\mathrm{HCO}_{3}{ }^{-}$ in lake water [34] and aragonite precipitation directly derived from the lake water $[55,68]$. The Lake Qinghai during the Early Holocene has a salty, low lake level under intensifying summer monsoon.

During the Middle Holocene (8.2-4.2 ka), the content of aragonite decreases gradually (Figure 8a) which is consistent with most of the other proxies indicating a gradually decreasing effective moisture (Figure 8b) and runoff (Figure 8c), reducing precipitation (Figure 8g) under weakening Asian summer monsoon (Figure $8 \mathrm{f}, \mathrm{h}$ ), their changes seem to be in contradiction with the increasing lake level indicating by negative $\delta^{13} \mathrm{C}$ of TOC (Figure 8e) and the evolution of Ostracod species from salty to brackish water (Figure 7i). The quartz content (Figure 7d) has gradually increased, which may be caused by intensified westerlies bringing more dust into the lake. Loess records nearly Lake Qinghai suggest the climate of the Middle Holocene is gradually becoming cold and dry $[13,15,16]$. We contribute the decreasing aragonite to weakening evaporation and cooling climate, which results in a high lake level.

Relative to early and Middle Holocene, the amplitude and frequency of all proxies (Figure 8) are small, indicating a relatively stable hydroclimate environment with low effective moisture and weak summer monsoon during the late Holocene in the Lake Qinghai area, although there are small peaks in curves of quartz, $\mathrm{Ca} / \mathrm{Ti}$ and $\delta^{13} \mathrm{C}$ of TOC. The temperature of the Late Holocene is relatively low as suggested by TOC, C/N ratio [31], and long-chain alkenone [69], and the lake level is about $20 \mathrm{~m}$ on average higher than the Early Holocene period [31]. Cold and deep water prevents aragonite precipitation to some extent, which causes lower mean aragonite content. 


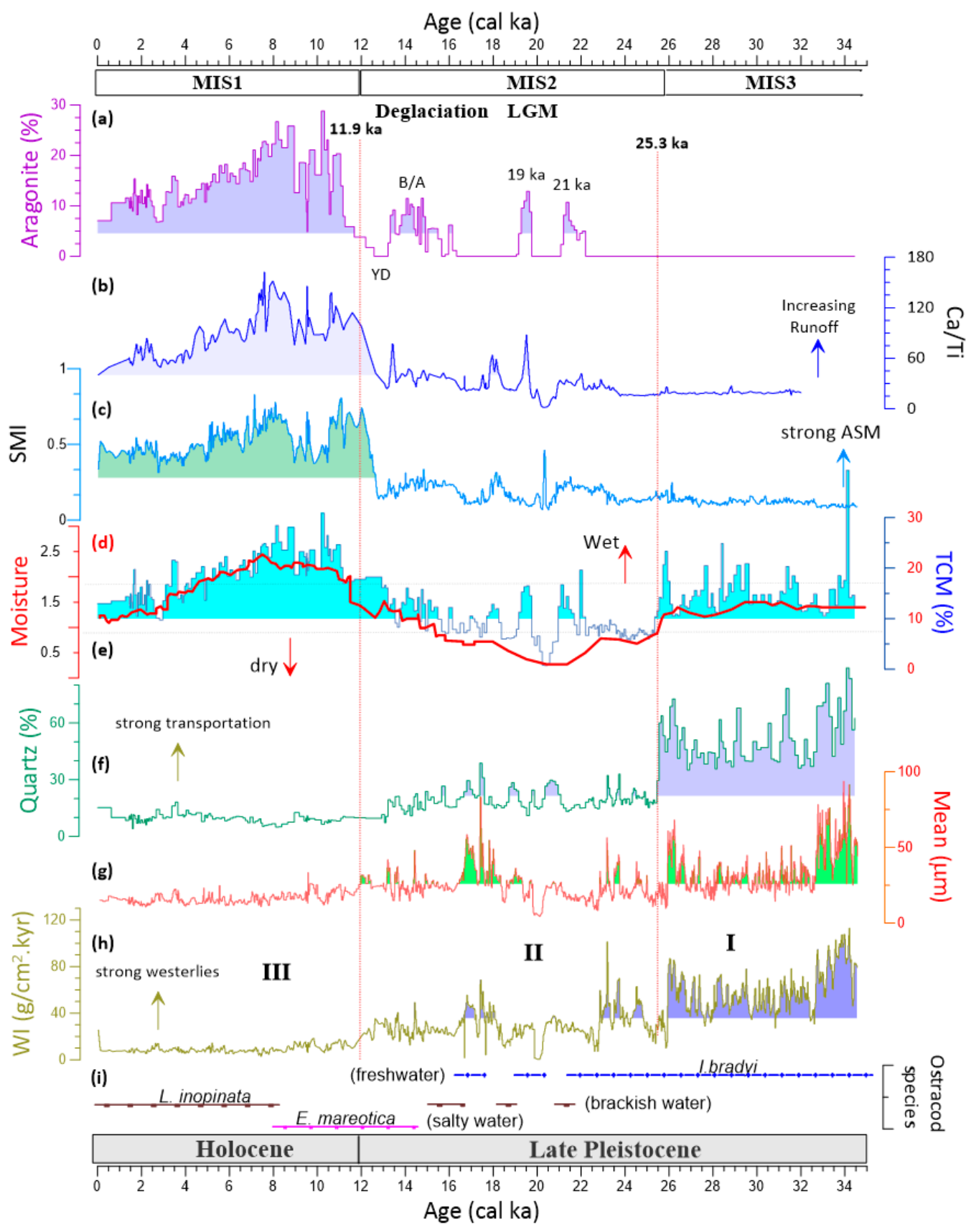

Figure 7. Multiple proxies comparison of 1Fs core from Lake Qinghai. (a) Aragonite content variations of bulk samples; (b) Ca/Ti ratio; (c) Summer Monsoon Index (SMI), Lake Qinghai Asian Summer Monsoon Index [1]; (d) Mean effective moisture in Asian monsoon margin [59], (e) Total Carbonate Minerals (TCM); (f) Quartz content variations of bulk samples; (g) Mean grain size [1]; (h) Westerlies Index (WI, the flux of $>25$ um fraction) [1]; (i): Ostracod species of 1Fs core [8]. YD: Younger Dryas, B/A: Bølling/Allerød. 

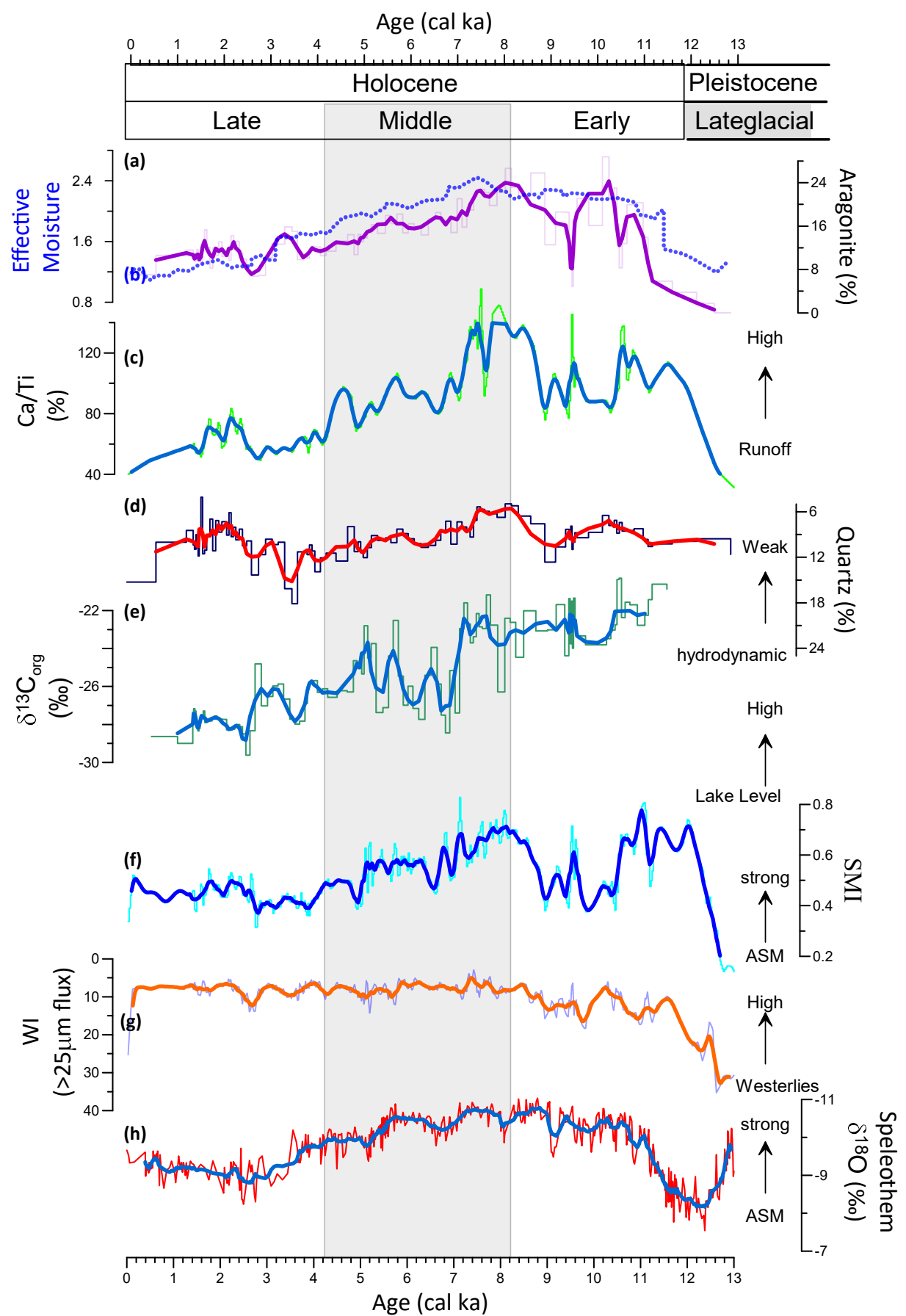

Figure 8. Lake Qinghai mineralogical records in $1 F$ s core compared to other sedimentological and biological reconstructions since the last $13 \mathrm{ka}$ (a) Mean effective moisture in the Monsoon margin area [59]. (b) Aragonite content variations of bulk samples; (c) Ca/Ti ratio from 1Fs core sediments; (d) Quartz content variations of bulk samples; (e) $\delta^{13} \mathrm{C}_{\text {org }}$ values of Total Organic Carbon (TOC); (f) Lake Qinghai Asian Summer Monsoon Index (SMI) [1]; (g) TOC flux in 1Fs core [1]; (h) $\delta^{18}$ O of East Asian speleothem [65]. 


\section{Conclusions}

X-Ray Diffraction results indicated that the predominant minerals of 1Fs core are quartz, aragonite, dolomite, and calcite. Based on the characteristics of mineral assemblages, together with sedimentary facies, we divided the $18.6 \mathrm{~m}$ long core into three stepwise stages at the depths of $11.65 \mathrm{~m}$ and $5 \mathrm{~m}$, representing three hydroclimate stages in the Lake Qinghai area. Asian Summer Monsoon circulation was relatively weak in this region during the period from $35 \mathrm{ka}$ to $25.3 \mathrm{ka}$, resulting in relatively cold and stable climatic conditions and shallow lake level. Minerals are characterized by larger amplitude and high-frequency fluctuations from $25.3 \mathrm{ka}$ to $11.9 \mathrm{ka}$, indicating a highly variable Lateglacial period with unstable hydroclimate. A predominant mineralogical shift from terrigenous quartz in the late Pleistocene to authigenic carbonates in Holocene indicates increasing lake levels, possibly due to an increase in the effective moisture balance. Since entering the Early Holocene, a warm and wet climate began at about $11.9 \mathrm{ka}$ and culminated around $8.2 \mathrm{ka}$ because of enhanced summer monsoon; the Middle Holocene climate became cooler and drier and has remained a relatively stable hydroclimate condition since $4.2 \mathrm{ka}$.

Author Contributions: Conceptualization, Y.S.; Data curation, L.Q. and H.L.; Formal analysis, Y.S., X.Z., L.Q., H.L., J.D. and M.Z.; Funding acquisition, Y.S.; Investigation, Y.S., L.Q., H.L., J.D. and H.C.; Methodology, X.Z. and M.Z.; Project administration, Y.S. and H.C.; Resources, Y.S.; Validation, Y.S. and X.Z.; Writing-original draft, Y.S. and X.Z.; Writing - review \& editing, Y.S. and J.D. All authors have read and agreed to the published version of the manuscript.

Funding: This research was funded by the Strategic Priority Research Program of the Chinese Academy of Sciences grant Nos: XDB26000000 and XDB40000000, State Key Laboratory of Loess and Quaternary Geology grant no SKLLQGPY2006, External Cooperation Program grant no 132B61KYSB20170005 of the Chinese Academy of Sciences, and Natural Science Foundation of China grant Nos. 41572162 and 40972230.

Acknowledgments: We express our heartfelt thanks to Zhisheng An and all the staff who took part in the Lake Qinghai Drilling Project for valuable data and sample collection, and we would like to appreciate very much for the support of the International Continental Drilling Program (ICDP) as well. We thank Editor Patrick Yang inviting us to write this manuscript. Our gratitude is also extended to Editor Irina Tene and the four anonymous reviewers for their constructive comments and suggestions.

Conflicts of Interest: The authors declare no conflict of interest.

\section{References}

1. An, Z.S.; Colman, S.M.; Zhou, W.J.; Li, X.Q.; Brown, E.T.; Jull, A.J.T.; Cai, Y.J.; Huang, Y.S.; Lu, X.F.; Chang, H.; et al. Interplay between the Westerlies and Asian monsoon recorded in Lake Qinghai sediments since $32 \mathrm{ka}$. Sci. Rep. 2012, 2, 619. [CrossRef]

2. Henderson, A.C.G.; Holmes, J.A.; Leng, M.J. Late Holocene isotope hydrology of Lake Qinghai, NE Tibetan Plateau: Effective moisture variability and atmospheric circulation changes. Quat. Sci. Rev. 2010, 29, 2215-2223. [CrossRef]

3. Henderson, A.C.G.; Holmes, J.A. Palaeolimnological evidence for environmental change over the past millennium from Lake Qinghai sediments: A review and future research prospective. Quat. Int. 2009, 194, 134-147. [CrossRef]

4. Colman, S.M.; Yu, S.Y.; An, Z.S.; Shen, J.; Henderson, A.C.G. Late Cenozoic climate changes in China's western interior: A review of research on Lake Qinghai and comparison with other records. Quat. Sci. Rev. 2007, 26, 2281-2300. [CrossRef]

5. Zeng, M.X.; Song, Y.G.; An, Z.S.; Chang, H.; Li, Y. Clay mineral records of the Erlangjian drill core sediments from the Lake Qinghai Basin, China. Sci. China Earth Sci. 2014, 57, 1846-1859. [CrossRef]

6. Fu, C.F.; An, Z.S.; Qiang, X.K.; Bloemendal, J.; Song, Y.G.; Chang, H. Magnetostratigraphic determination of the age of ancient Lake Qinghai, and record of the East Asian monsoon since 4.63 Ma. Geology 2013, 41, 875-878. [CrossRef]

7. Liu, W.; Zhang, P.; Cheng, Z.; Wang, H.; An, Z.; Hu, L. Reevaluation of carbonate concentration and oxygen isotope records from Lake Qinghai, the northeastern Tibetan Plateau. Quat. Int. 2018, 482, 122-130. [CrossRef] 
8. Li, X.; Liu, W. Lake evolution and hydroclimate variation at Lake Qinghai (China) over the past 32 ka inferred from ostracods and their stable isotope composition. J. Paleolimnol. 2017, 58, 299-316. [CrossRef]

9. Li, Y.; Wang, N.A.; Li, Z.L.; Zhou, X.H.; Zhang, C.Q.; Wang, Y. Carbonate formation and water level changes in a paleo-lake and its implication for carbon cycle and climate change, arid China. Front. Earth Sci. 2013, 7, 487-500. [CrossRef]

10. Liu, X.; Colman, S.M.; Brown, E.T.; An, Z.; Zhou, W.; Jull, A.J.T.; Huang, Y.; Cheng, P.; Liu, W.; Xu, H. A climate threshold at the eastern edge of the Tibetan plateau. Geophys. Res. Lett. 2014, 41, 5598-5604. [CrossRef]

11. Zhou, W.; Liu, T.; Wang, H.; An, Z.; Cheng, P.; Zhu, Y.; Burr, G.S. Geological record of meltwater events at Qinghai Lake, China from the past 40 ka. Quat. Sci. Rev. 2016, 149, 279-287. [CrossRef]

12. Lister, G.S.; Kelts, K.R.; Chen, K.Z.; Yu, J.Q.; Niessen, F. Lake Qinghai, China: Closed-basin lake levels and the oxygen isotope record for Ostracoda since the latest Pleistocene. Palaeogeogr. Palaeoclimatol. Palaeoecol. 1991, 84, 141-162. [CrossRef]

13. Ding, Z.; Lu, R.; Lyu, Z.; Liu, X. Geochemical characteristics of Holocene aeolian deposits east of Qinghai Lake, China, and their paleoclimatic implications. Sci. Total Environ. 2019, 692, 917-929. [CrossRef]

14. Liu, X.J.; Cong, L.; An, F.; Miao, X.; Chongyi, E. Downwind aeolian sediment accumulations associated with lake-level variations of the Qinghai Lake during the Holocene, Northeastern Qinghai-Tibetan Plateau. Environ. Earth Sci. 2019, 78, 19. [CrossRef]

15. Yu, L.P.; Lai, Z.P. OSL chronology and palaeoclimatic implications of aeolian sediments in the eastern Qaidam Basin of the northeastern Qinghai-Tibetan Plateau. Palaeogeogr. Palaeoclimatol. Palaeoecol. 2012, 337-338, 120-129. [CrossRef]

16. Sun, W.; Zhao, S.; Pei, H.; Yang, H. The coupled evolution of mid- to late Holocene temperature and moisture in the southeast Qaidam Basin. Chem. Geol. 2019, 528, 119282. [CrossRef]

17. Wei, H.; Chongyi, E.; Zhang, J.; Sun, Y.; Li, Q.; Hou, G.; Duan, R. Climate change and anthropogenic activities in Qinghai Lake basin over the last 8500 years derived from pollen and charcoal records in an aeolian section. Catena 2020, 193, 104616. [CrossRef]

18. Cheng, L.; Song, Y.; Sun, H.; Bradák, B.; Orozbaev, R.; Zong, X.; Liu, H. Pronounced changes in paleo-wind direction and dust sources during MIS3b recorded in the Tacheng loess, northwest China. Quat. Int. 2020, 252, 122-134. [CrossRef]

19. Jin, Z.; An, Z.; Yu, J.; Li, F.; Zhang, F. Lake Qinghai sediment geochemistry linked to hydroclimate variability since the last glacial. Quat. Sci. Rev. 2015, 122, 63-73. [CrossRef]

20. Liu, X.; Vandenberghe, J.; An, Z.; Li, Y.; Jin, Z.; Dong, J.; Sun, Y. Grain size of Lake Qinghai sediments: Implications for riverine input and Holocene monsoon variability. Palaeogeogr. Palaeoclimatol. Palaeoecol. 2016, 449, 41-51. [CrossRef]

21. Zhang, P.X.; Zhang, B.Z.; Qian, G.M.; Li, H.J.; Xu, L.M. The study of paleoclimatic parameter of Qinghai Lake since Holocene. Quat. Sci. 1994, 14, 225-238.

22. Ji, S.; Xingqi, L.; Sumin, W.; Matsumoto, R. Palaeoclimatic changes in the Qinghai Lake area during the last 18,000 years. Quat. Int. 2005, 136, 131-140. [CrossRef]

23. Yu, J.Q.; Kelts, K.R. Abrupt changes in climatic conditions across the late-glacial/Holocene transition on the N. E. Tibet-Qinghai Plateau: Evidence from Lake Qinghai, China. J. Paleolimnol. 2002, 28, 195-206. [CrossRef]

24. Xiao, J.L.; Porter, S.C.; An, Z.S.; Kumai, H.; Yoshikawa, S. Grain Size of Quartz as an Indicator of Winter Monsoon Strength on the Loess Plateau of Central China during the Last 130,000 Yr. Quat. Res. 1995, 43, 22-29. [CrossRef]

25. Song, Y.; Zeng, M.; Chen, X.; Li, Y.; Chang, H.; An, Z.; Guo, X. Abrupt climatic events recorded by the Ili loess during the last glaciation in Central Asia: Evidence from grain-size and minerals. J. Asian Earth Sci. 2018, 155, 58-67. [CrossRef]

26. Xu, C.; Lin, L.Z.; Yang, B. Clay Mineral in Sediment of Qinghai Lake. Sci. Geol. Sin. 1989, 24, 348-354.

27. Li, X.; Liu, W.; Xu, L. Evaluation of lacustrine organic $\delta^{13} \mathrm{C}$ as a lake-level indicator: A case study of Lake Qinghai and the satellite lakes on the Tibetan Plateau. Palaeogeogr. Palaeoclimatol. Palaeoecol. 2019, 532, 109274. [CrossRef]

28. Ai, L.; Qiang, X.K.; Song, Y.G.; Ao, H.; An, Z.S. Identification of greigite in the late Pleistocene sediments of Lake Qinghai and its environmental implications. Chin. J. Geophys. 2011, 9, 2309-2316. (In Chinese with English abstract) 
29. Chen, L.M.; Jin, Z.D.; Wan, D.J.; Zhang, F. Spatial uniformity in the mineralogical and geochemical compositions of surface sediments in Lake Qinghai and their controlling factors. Limnology 2015, 16, 113-125. [CrossRef]

30. Liu, X.Q.; Shen, J.; Wang, S.M.; Yang, X.D.; Tong, G.B.; Zhang, E.L. A 16000-year pollen record of Qinghai Lake and its paleo-climate and paleoenvironment. Chin. Sci. Bull. 2002, 47, 1931-1936. [CrossRef]

31. Yu, J.; Zhang, L. Lake Qinghai: Paleoenvironment and Paleoclimate; Science Press: Beijing, China, 2008.

32. Thomas, E.K.; Huang, Y.S.; Morrill, C.; Zhao, J.T.; Wegener, P.; Clemens, S.C.; Colman, S.M.; Gao, L. Abundant C4 plants on the Tibetan Plateau during the Lateglacial and early Holocene. Quat. Sci. Rev. 2014, 87, 24-33. [CrossRef]

33. Dong, H.; Song, Y.; Zhang, M. Hydrological trend of Qinghai Lake over the last 60 years: Driven by climate variations or human activities? J. Water Clim. Chang. 2019, 10, 524-534. [CrossRef]

34. Jin, Z.; You, C.-F.; Wang, Y.; Shi, Y. Hydrological and solute budgets of Lake Qinghai, the largest lake on the Tibetan Plateau. Quat. Int. 2010, 218, 151-156. [CrossRef]

35. Sun, D.P.; Tang, Y.; Xu, Z.Q.; Han, Z.M. A preliminary investigation on chemical evolution of the Lake Qinghai water. Chin. Sci. Bull. 1991, 36, 1172-1174.

36. An, Z.S.; Wang, P.; Shen, J.; Zhang, Y.X.; Zhang, P.Z.; Wang, S.M.; Li, X.Q.; Sun, Q.L.; Song, Y.G.; Al, L.; et al. Geophysical survey on the tectonic and sediment distribution of Qinghai Lake basin. Sci. China Ser. D Earth Sci. 2006, 49, 851-861. [CrossRef]

37. Zhou, W.; Cheng, P.; Wang, H.; Zhu, Y.; Jull, A.J.T.; Wu, Z. ${ }^{14}$ C Chronostratigraphy for Qinghai Lake in China. Radiocarbon 2014, 56, 143-155. [CrossRef]

38. Blaauw, M.; Christen, J.A.; Bennett, K.D.; Reimer, P.J. Double the dates and go for Bayes-Impacts of model choice, dating density and quality on chronologies. Quat. Sci. Rev. 2018, 188, 58-66. [CrossRef]

39. Blaauw, M.; Christen, J.A. Flexible paleoclimate age-depth models using an autoregressive gamma process. Bayesian Anal. 2011, 6, 457-474.

40. Reimer, P.J.; Bard, E.; Bayliss, A.; Beck, J.W.; Blackwell, P.G.; Ramsey, C.B.; Buck, C.E.; Cheng, H.; Edwards, R.L.; Friedrich, M. IntCal13 and Marine13 radiocarbon age calibration curves 0-50,000 years cal BP. Radiocarbon 2013, 55, 1869-1887. [CrossRef]

41. Zeng, M.X.; Song, Y.G. Application of the Levenberg-Marquardt algorithm to X-ray diffraction quantitative phase analysis. Earth Sci. 2013, 38, 431-440.

42. Zeng, M.X.; Song, Y.G. Study on the Influencing Factors of the Levenberg-Marquardt Algorithm for X-ray Diffraction Quantitative Phase Analysis. Rock Miner. Anal. 2012, 31, 798-806.

43. Last, F.M.; Last, W.M. Lacustrine carbonates of the northern Great Plains of Canada. Sediment. Geol. 2012, 277, 1-31. [CrossRef]

44. Jin, Z.; You, C.-F.; Yu, T.-L.; Wang, B.-S. Sources and flux of trace elements in river water collected from the Lake Qinghai catchment, NE Tibetan Plateau. Appl. Geochem. 2010, 25, 1536-1546. [CrossRef]

45. Wan, D.; Jin, Z.; Wang, Y. Geochemistry of eolian dust and its elemental contribution to Lake Qinghai sediment. Appl. Geochem. 2012, 27, 1546-1555. [CrossRef]

46. Jin, Z.; Yu, J.; Wang, S.; Zhang, F.; Shi, Y.; You, C.-F. Constraints on water chemistry by chemical weathering in the Lake Qinghai catchment, northeastern Tibetan Plateau (China): Clues from Sr and its isotopic geochemistry. Hydrogeol. J. 2009, 17, 2037. [CrossRef]

47. Tomonaga, Y.; Brennwald, M.S.; Livingstone, D.M.; Kwiecien, O.; Randlett, M.-È.; Stockhecke, M.; Unwin, K.; Anselmetti, F.S.; Beer, J.; Haug, G.H.; et al. Porewater salinity reveals past lake-level changes in Lake Van, the Earth's largest soda lake. Sci. Rep. 2017, 7, 313. [CrossRef]

48. McHenry, L.J.; Kodikara, G.R.L.; Stanistreet, I.G.; Stollhofen, H.; Njau, J.K.; Schick, K.; Toth, N. Lake conditions and detrital sources of Paleolake Olduvai, Tanzania, reconstructed using X-ray Diffraction analysis of cores. Palaeogeogr. Palaeoclimatol. Palaeoecol. 2020, 556, 109855. [CrossRef]

49. Warrier, A.K.; Pednekar, H.; Mahesh, B.S.; Mohan, R.; Gazi, S. Sediment grain size and surface textural observations of quartz grains in late quaternary lacustrine sediments from Schirmacher Oasis, East Antarctica: Paleoenvironmental significance. Polar Sci. 2016, 10, 89-100. [CrossRef]

50. Dong, J.; An, Z.; Lu, F. Quantitively partition of eolian and hydromorphic components in lacustrine sediments: An example from lake Qinghai. J. Geomech. 2010, 16, 402-411.

51. Kalińska-Nartiša, E.; Stivrins, N.; Grudzinska, I. Quartz grains reveal sedimentary palaeoenvironment and past storm events: A case study from eastern Baltic. Estuar Coast. Shelf Sci. 2018, 200, 359-370. [CrossRef] 
52. Morellón, M.; Valero-Garcés, B.; Moreno, A.; González-Sampériz, P.; Mata, P.; Romero, O.; Maestro, M.; Navas, A. Holocene palaeohydrology and climate variability in northeastern Spain: The sedimentary record of Lake Estanya (Pre-Pyrenean range). Quat. Int. 2008, 181, 15-31. [CrossRef]

53. Zhou, H.; Guo, G.; Yu, S. Quartz content of core SX97 in Zhoujiang River Estuary and its indication for climatic and environmental changes. J Trop. Ocenogr. 2001, 20, 1-5.

54. Gierlowski-Kordesch, E.H. Lacustrine carbonates. Dev. Sedimentol. 2010, 61, 1-101.

55. Liu, X.; Colman, S.M.; Brown, E.T.; Henderson, A.C.G.; Werne, J.P.; Holmes, J.A. Abrupt deglaciation on the northeastern Tibetan Plateau: Evidence from Lake Qinghai. J. Paleolimnol. 2014, 51, 223-240. [CrossRef]

56. McCormack, J.; Nehrke, G.; Jöns, N.; Immenhauser, A.; Kwiecien, O. Refining the interpretation of lacustrine carbonate isotope records: Implications of a mineralogy-specific Lake Van case study. Chem. Geol. 2019, 513, 167-183. [CrossRef]

57. LZBCAS. Evolution of Recent Environment in Qinghai Lake and Its Prediction, 1st ed.; Science Press: Beijing, China, 1994.

58. Talbot, M.; Kelts, K. Primary and diagenetic carbonates in the anoxic sediments of Lake Bosumtwi, Ghana. Geology 1986, 14, 912-916. [CrossRef]

59. Herzschuh, U. Palaeo-moisture evolution in monsoonal Central Asia during the last 50,000 years. Quat. Sci. Rev. 2006, 25, 163-178. [CrossRef]

60. Wang, Y.B.; Liu, X.Q.; Herzschuh, U. Asynchronous evolution of the Indian and East Asian Summer Monsoon indicated by Holocene moisture patterns in monsoonal central Asia. Earth-Sci. Rev. 2010, 103, 135-153. [CrossRef]

61. Yang, X.P.; Scuderi, L.; Paillou, P.; Liu, Z.T.; Li, H.W.; Ren, X.Z. Quaternary environmental changes in the drylands of China-A critical review. Quat. Sci. Rev. 2011, 30, 3219-3233. [CrossRef]

62. Wang, Y.; Herzschuh, U.; Shumilovskikh, L.S.; Mischke, S.; Birks, H.J.B.; Wischnewski, J.; Böhner, J.; Schlütz, F.; Lehmkuhl, F.; Diekmann, B. Quantitative reconstruction of precipitation changes on the NE Tibetan Plateau since the Last Glacial Maximum-extending the concept of pollen source-area to pollen-based climate reconstructions from large lakes. Clim. Past Discuss. 2014, 10, 536-552. [CrossRef]

63. Dykoski, C.A.; Edwards, R.L.; Cheng, H.; Yuan, D.; Cai, Y.; Zhang, M.L.; Lin, Y.S.; Qing, J.M.; An, Z.S.; Revenaugh, J. A high-resolution, absolute-dated Holocene and deglacial Asian monsoon record from Dongge Cave, China. Earth Planet. Sci. Lett. 2005, 233, 71-86. [CrossRef]

64. Wang, Y.; Cheng, H.; Edwards, R.L.; Kong, X.; Shao, X.; Chen, S.; Wu, J.; Jiang, X.; Wang, X.; An, Z. Millennialand orbital-scale changes in the East Asian monsoon over the past 224,000 years. Nature 2008, 451, 1090-1093. [CrossRef] [PubMed]

65. Cheng, H.; Edwards, R.L.; Sinha, A.; Spotl, C.; Yi, L.; Chen, S.; Kelly, M.; Kathayat, G.; Wang, X.; Li, X.; et al. The Asian monsoon over the past 640,000 years and ice age terminations. Nature 2016, 534, 640-646. [CrossRef] [PubMed]

66. Li, Y.; Song, Y.G.; Lai, Z.P.; Han, L.; An, Z.S. Rapid and Cyclic Dust Accumulation during MIS 2 in Central Asia Inferred from Loess OSL Dating and Grainsize Analysis. Sci. Rep. 2016, 6, 32365. [CrossRef]

67. Railsback, L.B.; Brook, G.A.; Chen, J.; Kalin, R.; Fleisher, C.J. Environmental controls on the petrology of a Late Holocene speleothem from Botswana with annual layers of aragonite and calcite. J. Sediment. Res. 1994, 64, 147-155.

68. Zhang, P.X.; Zhang, B.Z.; Yang, W.B. On the model of post-glacial palaeoclimatic fluctuation in Qinghai lake region. Quat. Sci. 1989, 9, 66-77.

69. Wang, Z.; Liu, Z.; Zhang, F.; Fu, M.; An, Z. A new approach for reconstructing Holocene temperatures from a multi-species long chain alkenone record from Lake Qinghai on the northeastern Tibetan Plateau. Org. Geochem. 2015, 88, 50-58. [CrossRef]

Publisher's Note: MDPI stays neutral with regard to jurisdictional claims in published maps and institutional affiliations. 